\title{
A threatened new species of Ipomoea (Convolvulaceae) from the Brazilian Cerrado revealed by morpho-anatomical analysis
}

\author{
Diego Santos', Raysa Valéria Carvalho Saraiva², Tiago Massi Ferraz², \\ Emília Cristina Pereira Arruda ${ }^{3}$, Maria Teresa Buril'
}

I Programa de Pós-Graduação em Botânica, Laboratório de Sistemática Integrativa, Universidade Federal Rural de Pernambuco, Av. Manoel de Medeiros, s/n, Dois Irmãos, 50670-901, Recife, Pernambuco, Brazil 2 Programa de Pós-Graduação em Agroecologia, Universidade Estadual do Maranhão, Av. Lourenço Vieira da Silva, s/n, Jardim São Cristóvão, 65055-970, São Luís, Maranhão, Brazil 3 Departamento de Botânica, Laboratório de Anatomia Vegetal, Universidade Federal de Pernambuco, Av. Prof. Moraes Rego, 1235, Cidade Universitária, 50670-901, Recife, Pernambuco, Brazil

Corresponding author: Diego Santos (fdsantosbot@gmail.com)

Academic editor: L. Giacomin | Received 3 January 2020 | Accepted 12 May 2020 | Published 17 June 2020

Citation: Santos D, Saraiva RVC, Ferraz TM, Arruda ECP, Buril MT (2020) A threatened new species of Ipomoea (Convolvulaceae) from the Brazilian Cerrado revealed by morpho-anatomical analysis. PhytoKeys 151: 93-106. https:// doi.org/10.3897/phytokeys.151.49833

\begin{abstract}
A new species of Ipomoea, endemic to the Cerrado domain in Maranhão, Brazil, is described. Ipomoea maranhensis D.Santos \& Buril, sp. nov. has been misidentified as I. burchellii Meisn. in several herbaria. Even though both species have oblong, pubescent leaves, they can be distinguished by morpho-anatomical characters. We present a diagnosis, complete description, illustration, taxonomic comments, conservation status and distribution map.
\end{abstract}

\section{Keywords}

biodiversity, Brazilian flora, conservation, endangered species, endemic species, morpho-anatomy, South America 


\section{Introduction}

Ipomoea (Convolvulaceae) comprises approximately 700 species (Staples 2015) and is widely distributed throughout the world, but is predominantly pantropical and absent in Mediterranean areas and temperate climates (Staples and Brummitt 2007). In Brazil, it is represented by 149 species distributed in all regions and phytogeographic domains (Flora do Brasil 2019). The genus can be distinguished by its echinate pollen (Simão-Bianchini 1998). Recently, knowledge of Ipomoea has been increased with the publication of several new species (e.g. Wood et al. 2015; Vasconcelos et al. 2016; Wood et al. 2017a, b; Wood and Scotland 2017a, b), many of which are endemic to Brazil (Wood et al. 2017c; Santos et al. 2019; Santos et al. in press).

Among Brazilian phytogeographic domains, the Cerrado stands out as a center of diversity and endemism for several plant groups (Simon et al. 2009). Despite being one of the 34 global biodiversity hotspots (Mittermeier et al. 2004), this domain has been intensely devastated in recent decades due to the expansion of agriculture and livestock (Cunha et al. 2008). Of the 12,113 Cerrado angiosperm species (BFG 2018), 366 are considered endangered (Martinelli et al. 2014). The genus Ipomoea is represented by 92 species in the Cerrado biome, which corresponds to $22 \%$ of the family's diversity in the country (Flora do Brasil 2019). Of these, I. macedoi Hoehne, I. maurandioides Meisn. and I. sobrevoluta Choisy are considered endangered and do not occur in protected areas (Martinelli and Moraes 2013), and may become extinct if we do not take any conservation initiative.

While analyzing Ipomoea collections from CEN, HST, HUEFS, and SLUI (acronyms follow Thiers 2019), we found a morphotype collected in the municipality of Carolina, Chapada das Mesas National Park in the State of Maranhão, that was dubiously identified as I. burchellii Meisn. When we analyzed the protologue and the type collection of I. burchellii, we noted significant differences in the morphology and indumentum of sepals between this species and the morphotype. After analyzing several I. burchellii specimens, we found that these differences are consistent.

We consulted literature related to climbing and subshrubby species of Ipomoea from South America (O’Donell 1948; O’Donell 1959a, b; Simão-Bianchini 1998; Léon 2006; Krapovickas 2009; Wood et al. 2015; Wood et al. 2017a, b, c; Wood and Scotland 2017a, b), type specimens from online database (http://plants.jstor. org), and Brazilian herbaria through SpeciesLink network (http://www.splink.org.br) in order to investigate similiar species to this morphotype. However, the combination of morphological features found in the morphotype did not match those of any known species.

To support the morphological delimitation between this morphotype and $I$. burchellii, we performed a comparative anatomical analysis of the leaf, as this has been used to support the morphological delimitation of species in various plant groups (Lersten 1974; Gomes et al. 2005; Rio et al. 2005; Oliveira et al. 2011; Thadeo et al. 2014), as well as in Convolvulaceae (Ketjarun et al. 2016; Traiperm et al. 2017). Thus, 
considering the taxonomic alleged consistency of the anatomical characters analyzed in Convolvulaceae (Metcalfe and Chalk 1979), along with the morphological discontinuities found, we describe this morphotype as a new species.

\section{Methods}

\section{Morphological analysis}

We analyzed specimens from the following herbaria: CEN, HUEFS, SLUI (acronyms follow Thiers 2019), and HST (unindexed herbarium from the Universidade Federal Rural de Pernambuco). Morphological terminology followed Harris and Harris (1994). The specimen collected in the Carolina municipality, Chapada das Mesas National Park, Maranhão state, was preserved according to standard taxonomic techniques (Mori et al. 1989) and deposited in SLUI. The main diagnostic characters of the species were illustrated based on the type specimen.

\section{Comparative anatomical analysis of the leaf}

For comparative anatomical analyses, three $I$. burchellii specimens and two vouchers of the new species were included in this study (Table 1). Three leaves from the fourth node and parts of the petiole of each specimen were rehydrated according to Smith and Smith (1942). Then, the samples were placed in 2\% potassium hydroxide solution at room temperature for two hours. Subsequently, the material was washed with distilled water three times. The samples were progressively dehydrated from $10 \%$ alcohol until their final storage in 70\% ethanol (Johansen 1940). The median region of blade and petioles were free-hand sectioned and clarified with 50\% sodium hypochlorite and stained with safrablue (safranin and Astra-Blau, Bukatsch 1972). The slides were prepared with glycerin and fixed with enamel (Kraus and Arduin 1997). The slides were deposited into the Plant Anatomy Laboratory (LAVeg) at the Universidade Federal de Pernambuco. The analysis and documentation were performed under a Leica DM500 microscope. The anatomical terminology followed Metcalfe and Chalk (1979).

\section{Conservation status}

Distribution records were obtained from herbarium sheets. The conservation status was based on IUCN guidelines and criteria (IUCN 2019) using georeferenced data from cited collections. The area of occupancy (AOO) and extent of occurrence (EOO) were calculated using GeoCAT (Bachman et al. 2011). The distribution map was created using the QGIS version 2.7 software (QGIS Development Team 2015). 
Table I. List of vouchers sampled for comparative anatomical analysis of Ipomoea maranhensis and I. burchellii.

\begin{tabular}{lccc}
\hline \multicolumn{1}{c}{ Species/specimens } & Collection point & Voucher & Herbarium \\
\hline I. maranhensis & & & \\
specimen 1 & Ibipira, Mirador, Maranhăo state & L.P. Felix et al. 8136 & HST \\
specimen 2 & Carolina, Maranhăo state & R.V.C. Saraiva 107 & SLUI \\
I. burchellii & & & \\
specimen 1 & Canápolis, Bahia state & Yoshida-Arns, K. 557 & HUEFS \\
specimen 2 & São Desidério, Bahia state & A.M. Miranda 3787 & HST \\
specimen 3 & Paraiso, Goiás state & Irwin, H.S. 21745 & HUEFS \\
\hline
\end{tabular}

\section{Taxonomic treatment}

\section{Ipomoea maranhensis D. Santos \& Buril, sp. nov.}

urn:Isid:ipni.org:names:77209927-1

Figs 1, 2

Type. Brazil. Maranhão: município de Mirador, Ibipira, Parque Estadual do Mirador, 06²2'01"S, 44²2'00"W, 11 April 1998 (fl.), L.P. Félix et al. 8136 (holotype HUEFS38133, isotype HST8028).

Diagnosis. Ipomoea maranhensis differs morphologically from I. burchellii Meins. by its twining habit (vs. subshrubs), lanceolate (vs. oblong), long-acuminate (vs. acute) and densely sericeous (vs. hirsute) sepals.

Description. Vine, internodes $1-5 \mathrm{~cm}$ long, latex absent; stem pubescent with whitish trichomes. Leaf blade 3.3-7 ×0.9-2.3 cm, oblong, base cuneate, rounded to subcordate, apex obtuse, acute, apiculate, margin entire, pubescent on both surfaces, discolor, whitish on abaxial face, brochidodromous, 6-10 pairs of secondary veins, main vein prominent; petiole $2-3 \mathrm{~mm}$ long, canaliculate, pubescent, nectary near the apex of the petiole. Inflorescence of dichasial cymes reduced, bracteolate in the axils of the upper leaves, with 3-7 flowers; peduncle 2-3 mm long, pubescent; bracts $1.7-2 \times 0.5-0.8 \mathrm{~cm}$, elliptical, base cuneate, apex obtuse, pubescent, foliaceous, discolor; pedicel $2-4 \mathrm{~mm}$ long, pubescent; bracteoles $0.9-1.6 \mathrm{~cm}$ long, lanceolate, oblong, base truncate, apex acute, obtuse, margin entire, pubescent. Sepals all equal, 1.7-2.3 $\times$ $0.4-0.5 \mathrm{~cm}$, lanceolate, base cuneate, apex long-acuminate, margins non-membranous, densely sericeous on the adaxial surface of the sepals, whitish. Corolla ca. $4 \mathrm{~cm}$ long, ca. $4.5 \mathrm{~cm}$ diam, infundibuliform, tube ca. $1.6 \mathrm{~cm}$ long, rose with whitish tube, midpetaline bands area sericeous externally. Stamens ca. $3 \mathrm{~cm}$ long, included, unequal, pilose at the base, anthers ca. $4 \mathrm{~mm}$ long, oblong, white. Ovary ca. $4 \mathrm{~mm}$ long, conical, glabrous, 4 locule; style ca. $2 \mathrm{~cm}$ long, glabrous; stigma bi-globose, papillose. Fruit unknown.

Anatomical description - petiole and leaf blade. Petiole epidermis uniseriate with juxtaposed cells, parenchyma with isodiametric cells, prominent/concave main rib shape, U-shaped vascular bundles. Leaf epidermis uniseriate, mesophyll dorsiventral with crystallized idioblasts (druses), palisade parenchyma with one to two layers of elongated 


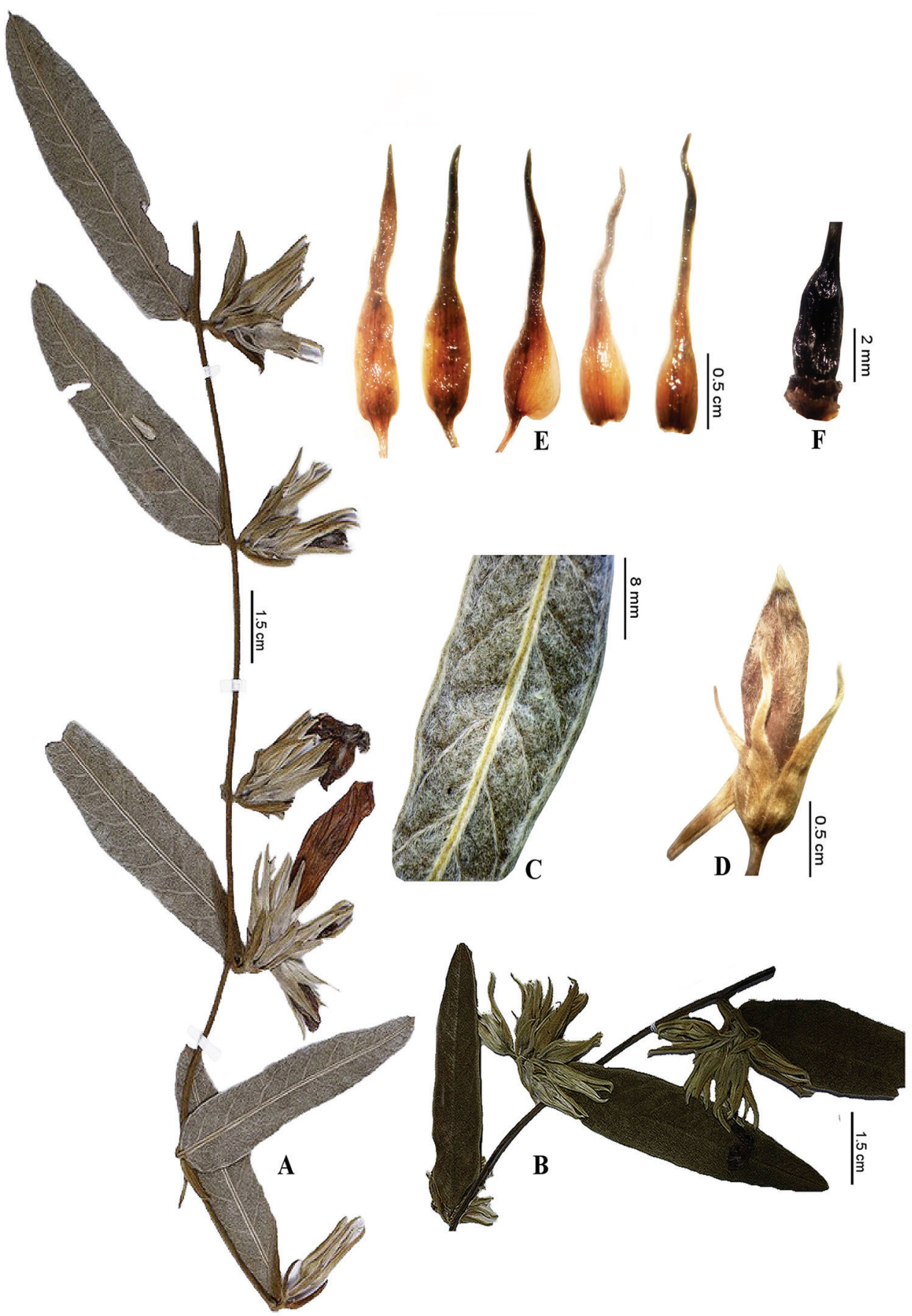

Figure I. A-F Ipomoea maranhensis A branch with leaves (abaxial surface) and flowers B branch with leaves (adaxial surface) and floral buds $\mathbf{C}$ leaf in abaxial view presenting sericeous aspect $\mathbf{D}$ floral bud E sepals $\mathbf{F}$ ovary (Photos by F. Santos and Flora do Brasil 2019). 


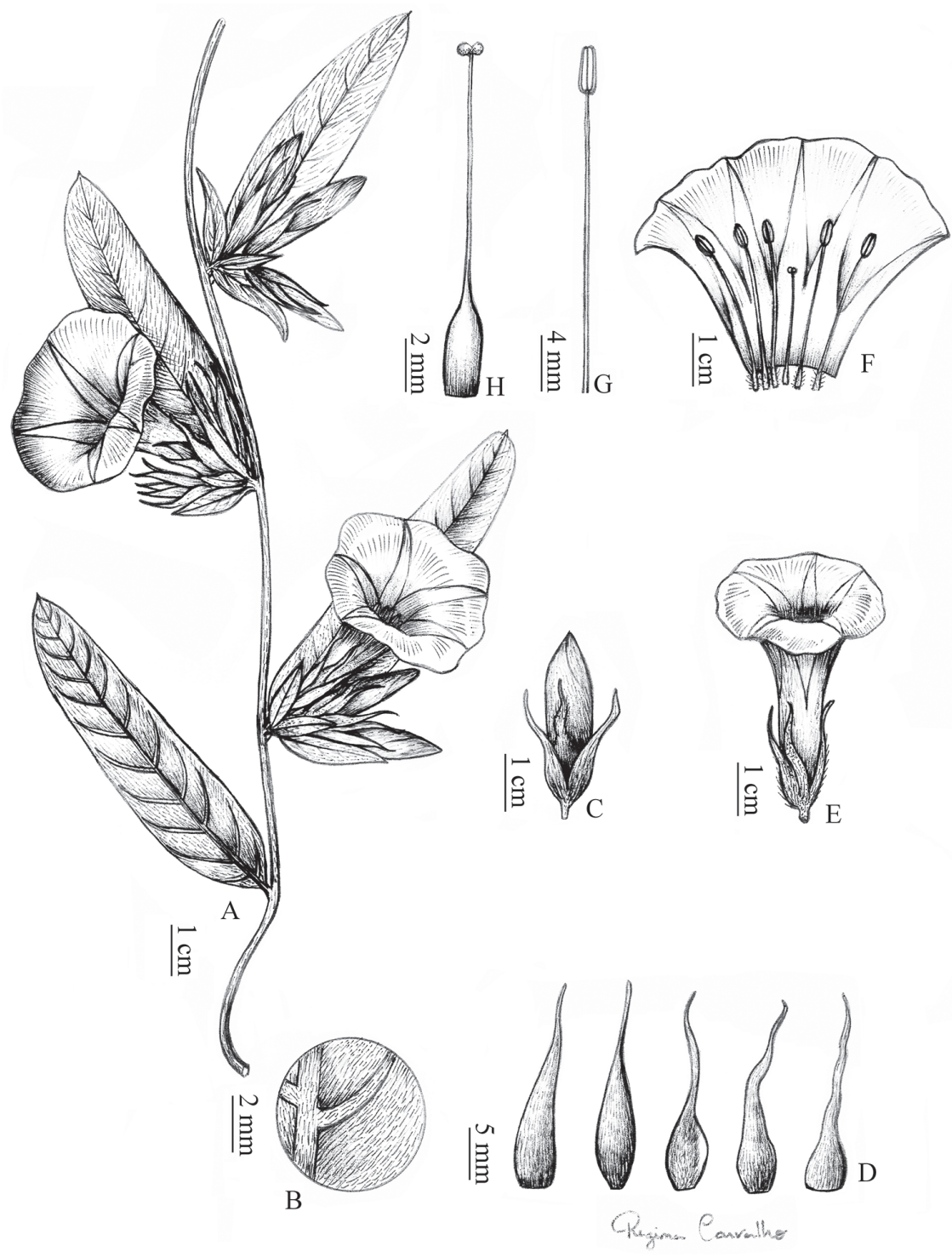

Figure 2. A-H Ipomoea maranhensis $\mathbf{A}$ twining habit $\mathbf{B}$ primary and secondary veins on the abaxial surface $\mathbf{C}$ floral bud $\mathbf{D}$ sepals with apex long acuminate $\mathbf{E}$ flower $\mathbf{F}$ open corolla $\mathbf{G}$ stamen $\mathbf{H}$ gynoecium. Drawn by Regina Carvalho from Félix et al. 8136.

Table 2. Comparison of morpho-anatomical characters of Ipomoea maranhensis and I. burchellii.

\begin{tabular}{lcc}
\hline \multicolumn{1}{c}{ Characters } & I. maranhensis & I. burchellii \\
\hline Shape of sepals & Lanceolate & Oblong \\
Apex of sepals & Acuminate & Acute \\
Indumentum of sepals & Sericeous & Hirsute \\
Arrangement of vascular bundles & U-shaped & V-shaped \\
Glandular trichomes on leaf & Both surfaces & Abaxial surface \\
Type of mesophyll & Dorsiventral & Isobilateral \\
\hline
\end{tabular}



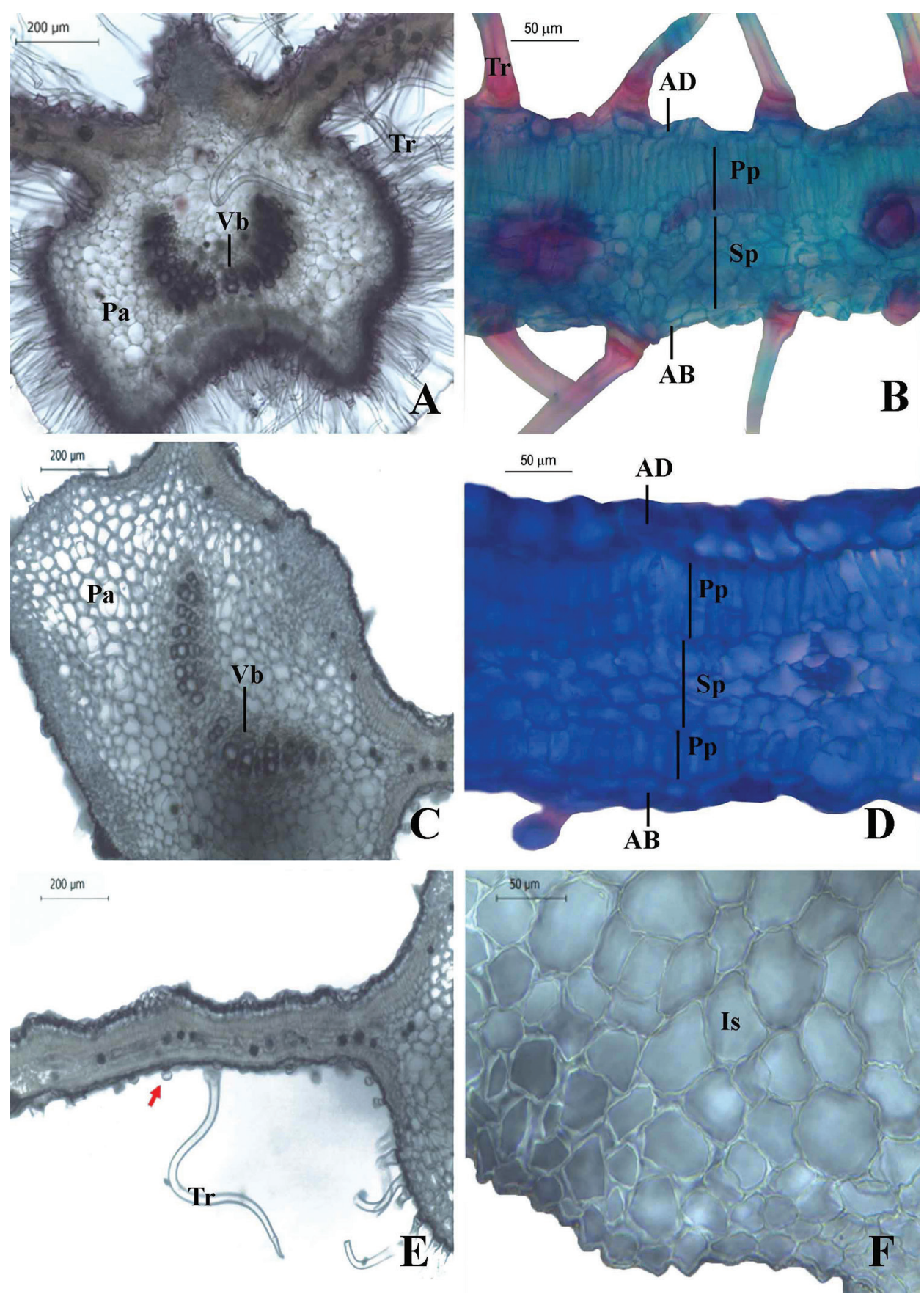

Figure 3. A, B Ipomoea maranhensis $\mathbf{A}$ arrangement of vascular bundles in $\mathrm{U}$; prominent/concave main rib shape B dorsiventral mesophyll C-F I. burchellii $\mathbf{C}$ arrangement of vascular bundles in V; convex/flat main rib shape $\mathbf{D}$ mesophyll isobilateral $\mathbf{E}$ glandular trichomes restricted to the abaxial surface of the leaf (red arrow) $\mathbf{F}$ parenchymatous tissue with isodiametric cells (Photos by E. Pereira Arruda). AD: adaxial epidermis; AB: abaxial epidermis; Is: isodiametric cells; Pa: Parenchymatous tissue; Pp: palisade parenchyma; Sp: spongy parenchyma; Vb: vascular bundle; Tr: trichome. 


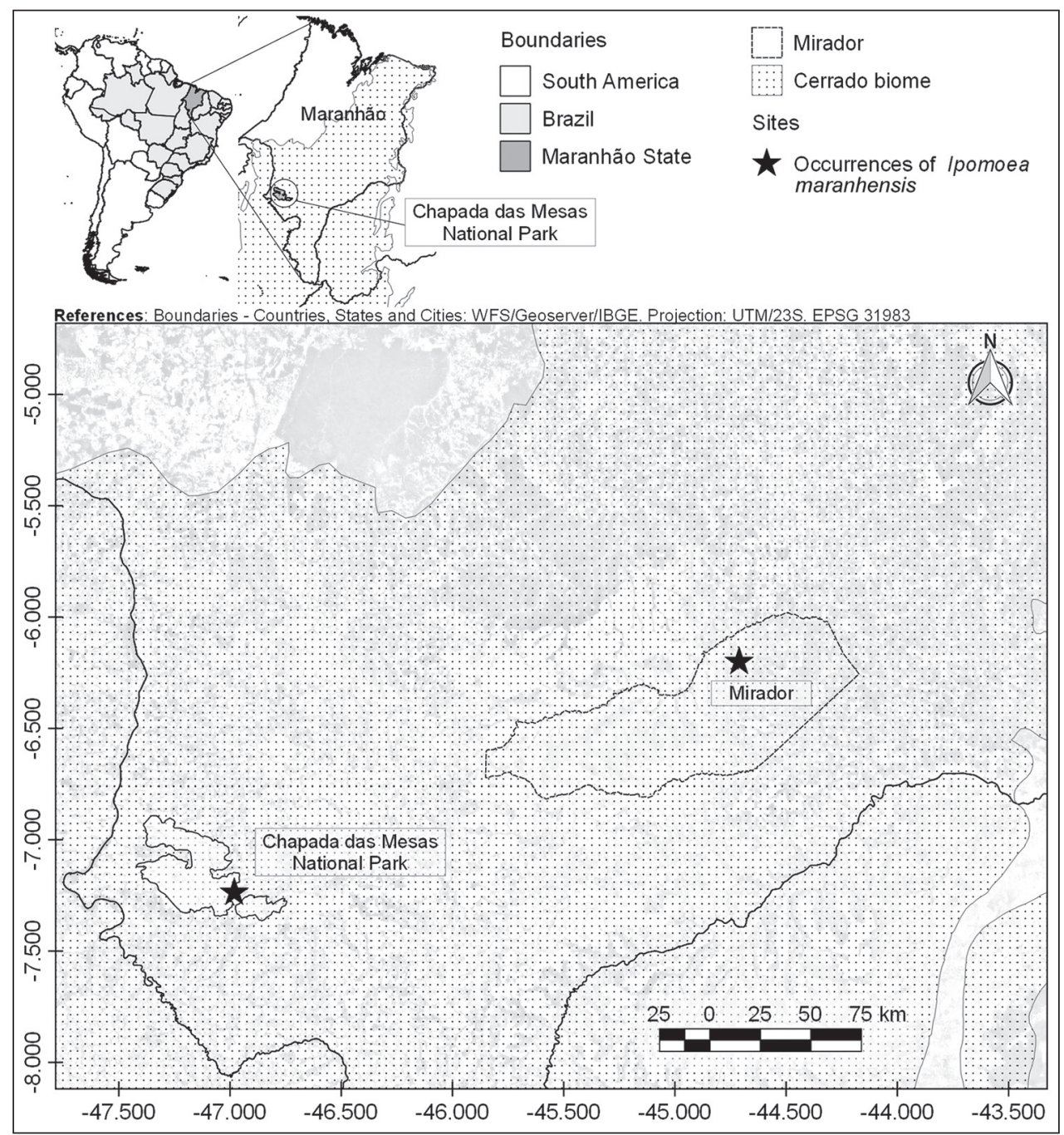

Figure 4. Distribution map of Ipomoea maranhensis.

cells more evident on the adaxial surface, spongy parenchyma with three to four layers of round cells with sinuous anticlinal walls; glandular trichomes on both leaf surfaces.

According to the anatomical analysis, we observed that $I$. maranhensis and $I$. burchellii share mesophyll with crystallized idioblasts (druses) and petiole parenchyma with isodiametric cells. However, I. maranhensis is distinguished from I. burchellii by a prominent/concave main rib shape (vs. convex/flat main rib shape in I. burchellii), Ushaped vascular bundles (vs. V-shaped), glandular trichomes spread on both leaf surfaces (vs. only on abaxial one) and dorsiventral mesophyll (vs. isobilateral) (Fig. 3) (Table 2).

Phenology. Collected with flowers in April.

Distribution and habitat. Ipomoea maranhensis is known only from two disjunct populations between the municipality of Mirador, in the Mirador State Park (area of 
$4370 \mathrm{~km}^{2}$ ) and the municipality of Carolina, in the National Park Chapada das Mesas (CMNP, area of $1600 \mathrm{~km}^{2}$ ) (Fig. 4). In both areas this species grows on quartzite soils associated with Cerrado vegetation at 186-345 m elevation, average temperature of $26^{\circ} \mathrm{C}$ and annual precipitation between 1250-1500 mm (Alcântara 2004; IBAMA 2013). The occurrence of this new species in the National Park Chapada das Mesas and in the Mirador State Park emphasizes the importance of these protected areas for the preservation of this taxon in the Cerrado domain.

Etymology. The specific epithet refers to Maranhão state, where the type specimens were collected.

Additional specimens examined. Brazil. Maranhão: Carolina, Parque Nacional da Chapada das Mesas, 345 m elev., 7¹4'14"S, 4658'50"W, 07 April 2017 (fl.), R.V.C. Saraiva 107 (SLUI 5037); Parque Nacional Chapada das Mesas, accesso no Km 596 da BR - 230, $7 \mathrm{~km}$ E em estrada vicinal, $290 \mathrm{~m}$ elev., 707'33"S, 47²2'13"W, 12 April 2016 (fl.), M.F. Simon et al. 2921 (CEN 95523).

Conservation status. We categorized this species as Endangered (criteria EN) according to $\mathrm{B} 1\left(\mathrm{EOO}<5000 \mathrm{~km}^{2}\right)$ and $\mathrm{B} 2 \mathrm{ab}$ (ii, iii) $\left(\mathrm{AOO}<500 \mathrm{~km}^{2}\right)$ from IUCN (2019). Although populations of I. maranhensis occur in protected areas, this species is threatened due to the reduction of its habitat because of anthropogenic fires lit by small communities who remove vegetation with fire for subsistence agriculture in the Cerrado sensu stricto and Cerradâo formations (Ribeiro and Walter 2008). According to Estivalet (1997), prostrate or climbing plants seem to be more prone to burning than upright species, whose growth points are more protected inside the clump.

Identification key for Ipomoea species from the Chapada das Mesas National Park and Mirador State Park

$1 \quad$ Leaf blade oblong, oblanceolate, linear or obovate .................................2

- Leaf cordate, hastate, lobed ............................................................5

2 Leaf linear; sepals obovate, elliptic, glabrous.............I. schomburgkii Meisn.

- Leaf oblong, oblanceolate, obovate; sepals oblong, ovate, lanceolate, sericeous, hirsute ..................................................................... 3

3 Leaf oblanceolate to obovate; sepals ovate ................... cuneifolia A. Gray

- Leaf oblong; sepals oblong or lanceolate.........................................4 4

4 Sepals oblong, obtuse, hirsute .................................... I. burchellii Meisn.

- Sepals lanceolate, long-acuminate, sericeous.......................I. maranhensis

5 Sepals with subapical rostrum; corolla hypocrateriform........I. hederifolia L.

- Sepals lacking subapical rostrum; corolla funnelform ...............................6

6 Leaf 5-lobed............................................................ mauritiana Jacq.

Leaf hastate or cordate .................................................................... 7

7 Outer sepals unequal in size ................................ I. maurandioides Meisn.

- Outer sepals equal in size ................................................................8

8 Sepals convex.................................................. I. goyazensis Gardner

- Sepals flat.............................................................. I. squamosa Choisy 


\section{Discussion}

The new species has been confused with $I$. burchellii because they share oblong, discolorous and sericeous leaves, flowers arranged in a dichasium and peduncle 2-3 mm long. However, according to the analysis of the type specimens (Burchell 8738 deposited in K [K000612855]) and protologue of I. burchellii, the new species is morphologically different from $I$. burchellii by its habit, shape, apex, and indumentum of sepals. Misidentifications probably occurred because both species have oblong, discolorous leaves, $2-3 \mathrm{~mm}$ long peduncles and inflorescence arranged in dichasium, as well as because they occur in the Cerrado domain. Anatomical analysis revealed that the morphological delimitation of these species is supported by the shape of the vascular bundles, distribution of glandular trichomes in the leaf and type of mesophyll.

These characters are considered consistent (Metcalfe and Chalk 1979) and useful for Convolvulaceae taxonomy (e.g. Ketjarun et al. 2016; Traiperm et al. 2017). Ipomoea maranhensis can also be compared to I. langsdorffii Choisy, an endemic species from the Southeastern region of Brazil occuring in the Cerrado and Atlantic forest, due to its oblong leaves and flowers in dichasia. However, I. maranhensis can be distinguished from this species by its acute leaves (vs. obtuse in I. langsdorffii), lanceolate (vs. ovate), long-acuminate (vs. acute), and densely sericeous (vs. hirsute) sepals. These morphological characters present great taxonomic value for Ipomoea (Simão-Bianchini 1998; Ferreira and Miotto 2009; Wood et al. 2015).

One of the barriers that can hinder access to knowledge about the diversity of the genus Ipomoea is that several of its new species have been described based on the morphology from one or two specimens without the without using a tool to support the morphological delimitation (Wood et al. 2017a, b). Such a limited number of specimens can lead to misinterpretation about the consistency of characters, making it difficult to recognize these species. In these cases, investigating other sources of characters is important for preventing the proliferation of names that cause taxonomic confusion and nomenclatural instability. Anatomical studies have been used to support the morphological delimitation of species in various plant groups (Smith and Smith 1942; Lersten 1974; Gomes et al. 2005; Rio et al. 2005). Among the leaf anatomical characters used to support such delimitation are mesophyll type, main vein shape, and vascular bundle type (Gomes et al. 2005; Gomes et al. 2008; Zini et al. 2016).

In Convolvulaceae, these characters have also been consistent and informative, such as the type of mesophyll that was used to delimit three species of Evolvulus (Ketjarun et al. 2016), the shape of the main vein and vascular bundles used to clarify the relationship between morphologically similar Argyrea species (Traiperm et al. 2017). Furthermore, anatomical characters strongly supported species identification in an investigation of Merremia section Xanthips (Pisuttimarn et al. 2013). Such anatomical information has been used in these studies because it has proven to be useful and informative for taxonomic identification of plants (Thadeo et al. 2014). 


\section{Acknowledgements}

We are grateful to the Conselho Nacional de Desenvolvimento Científico e Tecnológico (CNPQ) for the financial support for our field expeditions, under the project: "Sistemática de Convolvulaceae da América do Sul: construir em direção ao conhecimento global" (Process: PVE 314725/2014-8); the Coordenação de Aperfeiçoamento de Pessoal de Nível Superior (CAPES) for granting a scholarship to the first author; to Regina Carvalho for the illustrations; to the Fundação de Amparo à Pesquisa e ao Desenvolvimento Científico e Tecnológico do Maranhão (FAPEMA) for financial support, and Hannah Doerrier for English review.

\section{References}

Alcântara EH (2004) Caracterização da bacia hidrográfica do rio Itapecuru, Maranhão Brasil. Caminhos de Geografia 7(11): 97-113. http://files.nea.webnode.com/200000006-3cfc83df67/artigo07_vol11_Itapecuru.pdf

Bachman S, Moat J, Hill AW, De La Torre J, Scott B (2011) Supporting Red List threat assessments with GeoCAT: Geospatial conservation assessment tool. ZooKeys 150: 117-126. https://doi.org/10.3897/zookeys.150.2109

BFG (2018) Brazilian Flora 2020: innovation and collaboration to meet Target 1 of the Global Strategy for Plant Conservation (GSPC). Rodriguésia 69(4): 1513-1527. https://doi. org/10.1590/2175-7860201869402

Bukatsch F (1972) Bemerkungen zur Doppelfarbung. Microkosmos 61: 1-255.

Cunha NRS, Lima JE, Gomes MFM, Braga MJ (2008) A intensidade da exploração agropecuária como indicador da degradação ambiental na regiáo dos Cerrados, Brasil. Revista de Economia e Sociologia Rural 46(2): 1806-9479. https://doi.org/10.1590/S0103-20032008000200002

Estivalet Jr CNO (1997) Efeitos da ceifa, queima e diferimento sobre a disponibilidade e composição botânica de uma pastagem natural. Dissertação, Universidade Federal do Rio Grande do Sul, Porto Alegre, 97 pp.

Ferreira PPA, Miotto STS (2009) Sinopse das espécies de Ipomoea L. (Convolvulaceae) ocorrentes no Rio Grande do Sul. Revista Brasileira de Biociências 7(4): 440-453. http://hdl. handle.net/10183/27855

Flora do Brasil (2019) Ipomoea. Jardim Botânico do Rio de Janeiro. http://floradobrasil.jbrj. gov.br/reflora/floradobrasil/FB7021 [accessed 10.06.2019]

Gomes SMA, Silva EAM, Lombardi JA, Azevedo AA, Vale FHA (2005) Anatomia foliar como subsídio a taxonomia de Hippocrateoideae (Celastraceae) no Sudeste do Brasil. Acta Botanica Brasílica 19(4): 945-961. https://doi.org/10.1590/S0102-33062005000400029

Gomes SM, Somavilla NSDN, Gomes-Bezerra KM, Miranda SC, De-Carvalho OS, GracianoRibeiro D (2008) Anatomia foliar de espécies de Myrtaceae: Contribuiçôes à taxonomia e filogenia. Acta Botanica Brasílica 23(1): 223-238. https://doi.org/10.1590/S010233062009000100024 
Harris JG, Harris MW (1994) Plant identification terminology: an illustrated glossary. Spring Lake Publishing, Spring Lake, Utah, 197 pp.

IBAMA (2013) Plano Operativo De Prevenção e Combate aos Incêndios Florestais do Parque Nacional da Chapada das Mesas. Ministério do Meio Ambiente, Carolina. https://www. ibama.gov.br/phocadownload/prevfogo/planos_operativos/plano_operativoparna_da_ chapada_das_mesas.pdf [accessed 29.03.2017]

IUCN (2019) Guidelines for using the IUCN red list categories and criteria. Version 14. Standards and Petitions Committee. http://www.iucnredlist.org/documents/RedListGuidelines. pdf [accessed 11.05.2020]

Johansen DA (1940) Plant microtechnique. Mc Graw Hill Book Co. ilnc, New York and London, $511 \mathrm{pp}$.

Ketjarun K, Staples GW, Swangpol SC, Traiperm P (2016) Micromorphological study of Evolvulus ssp. (Convolvulaceae): The old world medicinal plants. Botanical Studies (Taipei, Taiwan) 57(1): 1-25. https://doi.org/10.1186/s40529-016-0141-y

Krapovickas A (2009) Novedades en Convolvuláceaes argentinas. Bonplandia 18(1): 57-64. https://doi.org/10.30972/bon.1811348

Kraus JE, Arduin M (1997) Manual básico de métodos em morfologia vegetal. Edur, Rio de Janeiro, 198 pp.

Léon B (2006) Convolvulaceae endémicas del Perú. Revista Peruana de Biología 13(2): 266267. http://www.scielo.org.pe/pdf/rpb/v13n2/v13n02a042.pdf

Lersten NR (1974) Morphology and distribution of colleters and crystals in relation to the taxonomy and bacterial leaf nodule symbiosis of Psychotria (Rubiaceae). American Journal of Botany 61(9): 973-981. https://doi.org/10.1002/j.1537-2197.1974.tb14037.x

Martinelli G, Messina T, Santos-Filho L (2014) Red Book of the Flora of Brazil-Rare Plants the Cerrado. Andrea Jakobsson, CNC Flora, Rio de Janeiro, 320 pp.

Martinelli G, Moraes MA (2013) Livro Vermelho da Flora do Brasil. Instituto de Pesquisas Jardim Botânico do Rio de Janeiro and Andrea Jakobson, Rio de Janeiro, 1100 pp.

Metcalfe CR, Chalk L (1979) Anatomy of dicotyledons (Vol. I). Systematic anatomy of the leaf and stem with a brief history of the subject ( $2^{\text {nd }}$ ed.). Clarendon Press, Oxford, $304 \mathrm{pp}$.

Mittermeier RA, Robles GP, Hoffmann M, Pilgrim J, Brooks T, Mittermeier CG, Lamoreux J, Fonseca GAB (2004) Hotspots Revisited: Earth's biologically richest and most endangered terrestrial ecoregions. CEMEX, Agrupación Sierra Madre, Mexico City, 392 pp.

Mori SA, Silva LAM, Lisboa G, Coradin L (1989) Manual de Manejo do Herbário Fanerogâmico ( $2^{\text {nd }}$ ed.). Centro de Pesquisas do Cacau, Ilhéus, Bahia, 104 pp.

O’Donell CA (1948) Convolvulaceae argentinas y paraguayas nuevas o críticas. Lilloa 14: 169-192.

O’Donell CA (1959a) Las species americanas de Ipomoea L. sect. Quamoclit (Moench) Griseb. Lilloa 29: 19-86.

O’Donell CA (1959b) Convolvulaceae argentinas. Lilloa 29: 87-348.

Oliveira MIU, Funch LS, Santos FAR, Landrum LR (2011) Aplicação de caracteres morfoanatômicos foliares na taxonomia de Campomanesia Ruiz \& Pavón (Myrtaceae). Acta Botanica Brasílica 25(2): 455-465. https://doi.org/10.1590/S0102-33062011000200021

Pisuttimarn P, Traiperm P, Pornpongrungrueng P (2013) Comparative anatomy of Merremia section Xanthips (Convolvulaceae) in Thailand. Proceedings in the National Graduate Research Conference 29 ${ }^{\text {th }}$ (NGRC29). Chiang Rai, Thailand, 93-101. 
Q GIS Development Team (2015) QGIS geographic information system. Open source geospatial Foundation Project, version 2.7.

Ribeiro JR, Walter BMT (2008) As principais fitofisionomias Cerrado. In: Sano SM, Almeida SP, Ribeiro JF (Eds) Cerrado: Ecologia e Flora. Embrapa, Brasília, 151-212.

Rio MC, Kinoshita L, Castro MM (2005) Anatomia foliar como subsídio para a taxonomia de espécies de Forsteronia G. Mey. (Apocynaceae) dos cerrados paulistas. Revista Brasileira de Botanica. Brazilian Journal of Botany 28(4): 713-726. https://doi.org/10.1590/S010084042005000400006

Santos FDS, Junior GCD, Baéz M, Pedrosa-Harand A, Queiroz JÁ, Quirino ZGM, Machado ICM, Buril MT (2019) Ipomoea vespertilia (Convolvulaceae), a new species revealed by pollinator observation. Brittonia 71(2): 190-195. https://doi.org/10.1007/s12228-018-09565-6

Santos D, Alencar J, Loiola MIB, Buril MT (in press) Ipomoea bonsai (Convolvulaceae), a Magnificent new Species from the Caatinga Domain, Brazil. Systematic Botany.

Simão-Bianchini R (1998) Ipomoea L. (Convolvulaceae) no Sudeste do Brasil. PhD Thesis, Universidade de São Paulo, Brazil.

Simon MF, Grether R, Queiroz LP, Skema C, Pennington RT, Hughes CE (2009) Recent assembly of the Cerrado, a neotropical plant diversity hotspot, by in situ evolution of adaptations to fire. Proceedings of the National Academy of Sciences of the United States of America 106(48): 20359-20364. https://doi.org/10.1073/pnas.0903410106

Smith FH, Smith EC (1942) Anatomy of the inferior ovary of Darbia. American Journal of Botany 29(6): 464-471. https://doi.org/10.1002/j.1537-2197.1942.tb10236.x

Staples GW (2015) Ipomoea L. World Checklist of Selected Plant Families. Kew, Royal Botanic Gardens. http://wcsp.science.kew.org/namedetail.do?name_id=480428 [accessed 22.03.2018]

Staples GW, Brummitt RK (2007) Convolvulaceae. In: Heywood VH, Brummitt RK, Culham A, Seberg O (Eds) Flowering Plant Families of the World. Royal Botanic Gardens, Kew, 108-110.

Thadeo M, Azevedo AA, Meira RM (2014) Foliar anatomy of neotropical Salicaceae: Potentially useful characters for taxonomy. Plant Systematics and Evolution 300(9): 2073-2089. https://doi.org/10.1007/s00606-014-1037-5

Thiers B (2019) Index Herbariorum: A global directory of public herbaria and associated staff. New York Botanical Garden's Virtual Herbarium. http://sweetgum.nybg.org/ih/ [accessed 12.05.2019]

Traiperm P, Chow J, Nopun P, Staples G, Swangpol SC (2017) Identification among morphologically similar Argyreia (Convolvulaceae) based on leaf anatomy and phenetic analyses. Botanical Studies (Taipei, Taiwan) 58(1): 1-25. https://doi.org/10.1186/s40529-017-0178-6

Vasconcelos LV, Simão-Bianchini R, França F (2016) Two new species of Ipomoea (Convolvulaceae) from the Chapada Diamantina of Bahia, Brazil. Brittonia 68(2): 142-147. https:// doi.org/10.1007/s12228-016-9411-y

Wood JRI, Scotland RW (2017a) Misapplied names, synonyms and new species of Ipomoea (Convolvulaceae) from South America. Kew Bulletin 72(1): 1-9. https://doi.org/10.1007/ s12225-017-9680-y

Wood JRI, Scotland RW (2017b) Notes on Ipomoea (Convolvulaceae) from the Amazonian periphery. Kew Bulletin 72(1): 1-10. https://doi.org/10.1007/s12225-017-9682-9

Wood JRI, Carine MA, Harris D, Wilkin P, Williams B, Scotland QW (2015) Ipomoea (Convolvulaceae) in Bolivia. Kew Bulletin 70(3): 1-31. https://doi.org/10.1007/s12225-015-9592-7 
Wood JRI, Buril MT, Scotland RW (2017a) Remarkable disjunctions in Ipomoea species (Convolvulaceae) from NE Brazil and Central America and Their taxonomic implications. Kew Bulletin 72(3): 1-44. https://doi.org/10.1007/s12225-017-9710-9

Wood JRI, Muńoz-Rodríguez P, Degen R, Scotland RW (2017b) New species of Ipomoea (Convolvulaceae) from South America. PhytoKeys 88: 1-38. https://doi.org/10.3897/ phytokeys.88.12891

Wood JRI, Vasconcelos LV, Simão-Binchini R, Scotland RW (2017c) New species of Ipomoea (Convolvulaceae) from Bahia. Kew Bulletin 72(1): 1-8. https://doi.org/10.1007/s12225017-9678-5

Zini AS, Martins S, Toderke ML, Temponi LG (2016) Anatomia foliar de Rubiaceae ocorrentes em fragmento florestal urbano d Mata Atlântica, PR, Brasil. Hoehnea 43(2): 173-182. https://doi.org/10.1590/2236-8906-59/2015 